depositions. If the report is requested by the defence, the solicitor will usually provide what is needed, although a few lawyers who rarely undertake criminal work may need gentle education about psychiatrists' needs. In Magistrates Court cases the situation is more difficult, as there are no depositions. Nonetheless it is usually possible, by polite persistence, to obtain useful information from the arresting police officer, the liaison probation officer, the defence solicitor, or the Crown Prosecution Service.

The recent experience of two of our Manchester forensic senior registrars, conducting a pilot study for a court duty psychiatrist diversion scheme, showed that being physically present in the Court complex was the ideal way both to obtain information and to arrange transfer of mentally abnormal offenders to psychiatric care. Joseph and James and Hamilton have made similar findings in two London Courts.

In conclusion, Dr Azuonye has a case but it is considerably overstated, despite some continuing difficulties in communication between the Courts and assessing psychiatrists. Representatives of the College are about to have what is likely to be the first of a series of meetings with the Law Society and the Bar Council about matters of joint interest, and I will take up this point with them, as well as drawing it to the attention of the joint Home Office and Department of Health Review on Mentally Disordered Offenders (Reed Committee).

A. A. Campbell Chairman

Edenfield Centre Forensic Section

Prestwich Hospital

Manchester M25 7BL

\section{Action on anomalous aspects of the Mental Health Act 1983}

DeAR SIRS

Since the Mental Health Act 1983 came into force, there has been a steady stream of papers, articles and letters pointing out aspects that are illogical, ambiguous, impossible of application, or inadequate in their provisions such as approval of doctors under Section 12(2) of the Act; unhappiness with the Draft Code of Practice; the provisions regarding appeals against detention under Section 37; application of Section 2; and the responsibilities and authority of Approved Social Workers. But despite the volume of persistent correspondence about the anomalies of the Act and the Code of Practice, nothing has changed.

If there is a department of the College that looks into issues surrounding the Mental Health Act, what is it doing by way of response to our observations?
If there is not, we must surely create one, to liaise between us and those who make the laws of the land, so as to draw their attention to the amendments that we would like to see made.

There has been some correspondence regarding whether forensic psychiatry is all we need to address the legal aspects of psychiatry, or whether a separate department is required. My answer is that forensic psychiatry is-or ought to be-about the intervention of psychiatrists in the management of mentally abnormal offenders. Forensic psychiatry should not be attempting to be the sole source of expert opinion on the legal aspects of psychiatry. Besides, since the mentally abnormal offenders constitute a small proportion of the mentally disordered, it is clear that forensic psychiatry could not address all of our questions about the provisions and application of the entire Mental Health Act.

IKECHUKWU O. AZUONYE

The London Hospital (St Clement's)

$2 a$ Bow Road

London E3 4LL

\section{DeAr Sirs}

Dr Azuonye is under the doubly mistaken impression that forensic psychiatrists wish to be the sole source of expert opinion on the legal aspects of psychiatry, such as Section 12 approval and the Code of Practice (no longer "Draft") and that the College has no influence on such matters. Most of these are vital to general psychiatrists, and are dealt with by the new General Psychiatry Section, by the Public Policy Committee or by E \& F (Executive and Finance), and come before Council. The College was effective in transforming the original Draft Code of Practice into something much more appropriate and makes useful recommendations about many other legal issues.

Forensic psychiatrists work with legal requirements most of the time, and should acquire extensive knowledge and experience of them. So legal issues are usually presented to the Forensic Section Executive for comment, as well as to other College committees, but the Section does not make College policy or claim the right to speak for the College as a whole.

We have an unusually democratic and representative Royal College, and as a former Division Chairman I advise Dr Azuonye to take up his concerns through his College Division or by joining appropriate Sections and Groups of the College. I see no need at present for a separate legal aspects of psychiatry department.

\section{Edenfield Centre}

A. A. CAmprell

Prestwich Hospital

Manchester M25 7BL 